\title{
Mobile Audience Interaction - Explaining the Adoption of New Mobile Service Applications in Socially Enriched Environments
}

\author{
Rita Faullant ${ }^{1}$, Johann Füller ${ }^{2}$ \& Kurt Matzler ${ }^{3}$ \\ ${ }^{1}$ Department of Innovation Management and Entrepreneurship, University of Klagenfurt, Klagenfurt, Austria \\ ${ }^{2}$ HYVE AG, Schellingstraße 45, 80799 Munich, Germany, and Department of Strategic Management, \\ Marketing and Tourism, University of Innsbruck, Innsbruck, Austria \\ ${ }^{3}$ Department of Strategic Management, Marketing and Tourism, University of Innsbruck, Innsbruck, Austria \\ Correspondence: Rita Faullant, Department of Innovation Management and Entrepreneurship, University of \\ Klagenfurt, Universitätsstrasse 65-67, 9020 Klagenfurt, Austria. Tel: 43-463-2700-052. E-mail: \\ rita.faullant@aau.at
}

$\begin{array}{lr}\text { Received: February 1, } 2012 \quad \text { Accepted: March 20, } 2012 \quad \text { Published: May 1, } 2012 \\ \text { doi:10.5539/emr.v1n1p59 } & \text { URL: http://dx.doi.org/10.5539/emr.v1n1p59 }\end{array}$

\begin{abstract}
Mobile communication with its rapidly evolving new functionalities and services has become one of the most important technological innovations over the last decade. The diffusion of such new services is, however, difficult to predict and the adoption of new mobile services might in fact be triggered by factors that have not been foreseen by traditional models of acceptance and diffusion. The technology acceptance model and the theory of planned behavior are the two main models discussed in the literature, both of which have been tested mainly in work or organizational contexts. Mobile services, however, are often used in socially enriched environments where the adoption and use of a mobile service is not solely a question of persuasion but also reflects individuals' need for relationships with others and with social groups. We have therefore extended the traditional models to reflect this fact and report here on the results of an online study which investigates intentions regarding adoption of a new mobile service application, namely mobile voting. The study was carried out in an online cinema community. Possible moderating effects of involvement, cell phone skills, and consumers' innovativeness are also investigated in this study.
\end{abstract}

Keywords: mobile services, technology acceptance, theory of planned behavior, online community, mobile marketing

\section{Introduction}

The acceptance of new technologies has been discussed in the scientific literature for almost two decades. Two theoretical models have been widely employed to explain adoption behavior: the technology acceptance model (TAM) proposed by Davis (1989), and a more general model for the prediction of human behavior, the theory of planned behavior (TPB) (Ajzen, 1988, 1991a). Previous research has focused on adoption behavior mainly in organizational or work contexts, and mostly on technology related to professional tasks (Davis, Bagozzi, \& Warshaw, 1989; Mathieson, 1991; Subramanian, 1994; Venkatesh \& Morris, 2000). TAM has also been used to explain the adoption of mobile services (Lu, Deng, \& Wang, 2010; Meso, Musa, \& Mbarika, 2005; Wang, Lin, \& Luarn, 2006). However, little is known about technology adoption in highly social contexts. Recently, Nysveen, Pedersen and Thorbjornsen (2005) have reported findings from a cross-services comparison of four mobile services, indicating that the strength of the various determinants of TAM and TPB varies substantially across service categories depending on whether the service is machine or person interactive. However, the widespread use of mobile devices and the emergence of multiple forms of computer-mediated communication make it necessary to go beyond traditional determinants of technology adoption such as usefulness and ease of use. Researchers have understood that the mode of use of various computer-mediated communication media is defined and appropriated through the social activities for which the medium is in actual fact used (Kim, Kim, Park, \& Rice, 2007). With our research study, we aim to extend the existing knowledge of technology adoption by investigating the drivers of the intention to adopt mobile services in highly social contexts such as 
communities. The technology under investigation, mobile audience interaction (or mobile voting), is in fact a new technology of which as yet only prototypes are available. Thus, distortion of the results due to different usage levels among respondents can effectively be excluded. The social context of the study is that of an online community in which social ties among members are higher than in usual samples. We investigate users' attitudes towards such services by using traditional components of TAM and TBP, but also by substantially supplementing these models by incorporating factors which take into account the distinctive features of social media use.

The contribution of this paper is threefold. First, we integrate the two theoretical models TAM and TPB and add further variables to better predict behavioral intentions. Second, we look at intentions to adopt technologies in socially enriched environments and identify additional determinants of attitudes in such contexts. Third, we test the impact of three important moderating variables on the relationships in our main model: involvement, skills, and consumers' innovativeness. Our analysis shows that traditional components play only a minor role in attitude formation while the added components of enjoyment and social value are the primary factors responsible for a positive attitude, which again is the main driver of intentions to use this technology. Furthermore, subjective norms (perceived social pressure) substantially influence users' intentions to use mobile voting.

The rest of the paper is structured as follows. In the following section, we describe our research context, and describe and classify mobile audience interaction as a new form of computer-mediated communication technology. We then review previous research on technology adoption using TPB and TAM, and argue that these two theoretical models can be integrated to explain the intentions to use mobile audience interaction. The discussion of the adoption of new technologies in socially enriched environments leads us to develop hypotheses to further extend TPB and TAM, including also the possible impact of moderating variables. In the next section we present the empirical study and finally we conclude the paper with a discussion of the findings and their implications.

\subsection{Mobile Audience Interaction}

Nowadays mobile phones, hand-held, and smart phones accompany us wherever we go. Mobile devices such as the Apple iPhone offer people new ways of interacting with each other and of actively engaging in events. New "mobile audience interaction" services offer individuals the opportunity to interact with large groups and also make it possible to conduct surveys independent of time and place. In this study, the term "audience interaction" refers to any survey-like type of interaction, evaluation, or opinion-stating communication which individuals engage in via their mobile devices. Mobile audience interaction (or mobile voting) not only offers several new departures in the field of marketing research (e.g. spontaneous reaction to an ad or product, evaluation of a shopping atmosphere), but also offers new possibilities for active interaction with large audiences during events. By utilizing new technology, formerly passive spectators may now become active participants and may even play a major role at events. For example, spectators at a soccer game might interact with each other to exchange comment on the performance of their team, and audience members at a casting show can discuss the talent of the various artists. Public opinion polls, real-time betting, and ultimately also mobile elections are further possible applications. From a firm's perspective, the advantage of such a mobile application is evident as it clearly helps managers to come closer to their customers and has the potential to make the feedback communication process much more efficient. Moreover, it represents important opportunities for the branding of companies and their products, as it increases brand awareness, enhances consumer involvement and interaction, and may directly influence consumer actions (Sultan \& Rohm, 2005). Users engaging in mobile voting may themselves also receive some benefits. For example, they may derive social value from the interaction with others or consider the activity itself to be enjoyable and rewarding. Especially in the age of Web 2.0, when mobile phones are being used, for example, as cameras to take pictures and videos to be uploaded onto the Internet or as global positioning devices to record and then post on Google Maps a route taken, it seems plausible that users indeed consider such services to be beneficial and desirable. However, until now, voting services have not found wide consumer acceptance and are not widely diffused.

\subsection{Classifying Mobile Voting}

From a customer perspective the motivation to engage in mobile voting processes may be manifold. Mobile voting is a form of computer-mediated communication technology. Therefore, it is useful to investigate relevant typologies that have been discussed in the literature. Using mobile voting enables the user to interact with others in an "impersonal" and anonymous way as the recipient of the message is in most cases an unknown large audience and the sender remains anonymous. One classification scheme for mobile service applications stems from interactivity research, where person-to-person interactivity is distinguished from machine interactivity or user-to-system interaction (Steuer, 1992). Using this classification system, mobile voting could best be 
subsumed under person-to-person interactivity, though the degree of interactivity differs from the standard case defined in the literature, where most authors consider interactivity to involve at least three exchange activities between sender and recipient (e.g. Rafaeli, 1988). Still we treat mobile voting as an interactive mobile application, and adopt the view of Bucy (2004), who claims to define interactivity from a user rather than from a technology perspective and therefore to understand it as a perceptual variable that involves communication mediated by technology (p. 377).

Hoffman and Novak (1996) distinguish between goal-directed processes, which are characterized by instrumental orientation and extrinsic motivation, and experiential processes, characterized by intrinsic motivation, hedonic benefits and non-directed search. Some of the mobile audience interaction applications may be employed in the service of goal-directed processes. For example, participation in a political election, participation in an opinion poll, and the completion of a marketing research questionnaire may all be seen as a means to the completion of a goal-directed process. Mobile audience interaction applications however do not correspond closely to the definition of experiential processes put forward by Hoffman and Novak (1996): real-time betting at a football game or active voting participation in casting shows may be elicited intrinsically, but they mostly lack navigational choice, non-directed search or ritualistic orientation as formulated by Hoffman and Novak. The concept of U-commerce elaborated by Watson, Pitt, Berthon and Zinkhan (2002) may actually be more suitable for classifying mobile audience applications. The U-commerce concept states that technology delivers value to consumers by either extending conscious interaction or reducing the need for such interaction (amplification vs. attenuation) in one dimension, and by adding value through time-space specificity or overcoming of time-space constraints in the other dimension. On trying to integrate mobile audience interaction applications within this framework, it becomes clear that such applications would create value for consumers on the "amplification" pole, as voting per se requires conscious processes. As to the time-space specificity dimension, mobile audience interaction applications may create value both in the time-space specific domain (e.g. mobile betting at soccer games) as well as the time-space independent domain (e.g. mobile voting).

Summarizing these efforts to characterize mobile audience interaction applications in terms of existing typologies, we can say that they are best understood as computer-mediated communication technologies that provide its users with interaction possibilities which enable them to amplify their conscious evaluation processes by overcoming time-space constraints or by taking advantage of the time-space specificity which has been created. In the context of our study, we tested mobile voting as a form of mobile audience interaction. Members of a virtual cinema community voted for their preferred actors, songs, etc. in two selected movies, and by doing this also evaluated the mobile voting technology.

\subsection{Adoption of Mobile Voting - Traditional Models}

As is the case with any other new technology that might make daily life easier or improve the effectiveness and efficiency of human actions, the actual adoption process is a vital issue for the diffusion of mobile voting technology. In the literature there are two theoretical concepts which are most often employed to explain the likelihood of a technology being used: the theory of planned behavior (TPB) (Ajzen, 1988), a model that tries to predict human behavior in a general fashion, and the technology acceptance model (TAM), which specifically focuses on the determining variables involved in the adopting of new technologies.

\subsubsection{Theory of Planned Behavior}

The theory of planned behavior (TPB) posits that three conceptually independent variables determine people's intention towards behavior: Attitude towards behavior describes a positive or negative evaluation or appraisal of the behavior in question, subjective norms refer to the presence of social pressure to perform a behavior or not, and third, perceived behavioral control denotes the perceived ease or difficulty of performing a behavior. The inclusion of the last determinant is an extension to the theory of reasoned action (TRA) (Ajzen \& Fishbein, 1980), which accounts for the possibility that human behavior is not always fully subject to volitional control, and that both external and internal factors may restrict the execution of behavior. This theory takes into account past experience as well as anticipated impediments (such as shortage of money or resources) (Ajzen, 1991a). Importantly, the intention whether or not to perform a behavior is determined by the perceived behavioral control of an individual, which may differ from actual control (Ajzen, 2002). In information systems research, a similar component, self-efficacy, has been integrated. This denotes an individual's belief in his/her ability to perform a specific task in a given situation, and has been found to influence mobile text messaging (Mahatanankoon \& O'Sullivan, 2008). In general, the more favorable the attitude and the subjective norm and the greater the perceived behavioral control, the stronger is an individual's intention to perform the corresponding behavior. Intentions are assumed to capture the motivational factors that influence behavior and describe how hard a 
person will try to perform a certain behavior (Ajzen, 1991a, p. 181). Although there is no total correspondence between attitude toward a behavior, behavioral intention, and actual behavior, Fishbein and Middlestadt (1995) consider a person's intention to be the most appropriate predictor for his/her behavior. The behavior in question in this study is the intention to use mobile voting, which would then be seen as a direct predictor for the actual adoption of this new technology. We integrate all three components proposed by the theory of planned behavior, assuming that a positive attitude towards this new technology is necessary for the intention to use it. Furthermore, especially in the case of new social media, where social interaction is a central motivation for usage, we expect that the perceived social pressure (or subjective norms) will significantly determine an individual's intention to use mobile voting technology. And finally, an individual's perceived personal capabilities and restrictions will also condition his/her intentions to use mobile voting. Therefore we posit the following hypotheses:

H1: An individual's attitude towards mobile voting positively influences the intention to use mobile voting.

$\mathrm{H} 2$ : The subjective norm positively influences the individual's intention to use mobile voting.

H3: The perceived behavioral control regarding using mobile voting positively influences the individual's intention to use mobile voting.

\subsubsection{Technology Acceptance Model}

The technology acceptance model (TAM) introduced by Davis (1989) has been developed specifically to predict the adoption of technologies, mostly in work contexts. It is an important modification that has developed out of the theory of reasoned action (Ajzen \& Fishbein, 1980). The TAM posits that the intention to adopt new technologies depends upon an individual's attitude towards using the technology in question, which in turn is a function of its perceived usefulness for its users and the perceived ease of use. While perceived usefulness denotes "the degree to which a person believes that using a particular system would enhance his or her job performance", perceived ease of use refers to "the degree to which a person believes that using a particular system would be free of effort". Whereas a lack of perceived ease of use may hinder the adoption of an otherwise useful system, no amount of ease of use can compensate for lack of usefulness (Davis, et al., 1989). In TAM and further extended models, perceived usefulness and perceived ease of use are assumed to influence attitudes towards an object or technology. From the perspective of the theory of planned behavior, these two components thus feature as behavioral beliefs which influence the attitude towards behavior:

H4: Perceived usefulness of mobile voting positively influences the attitude towards mobile voting.

H5: Perceived ease of use of mobile voting positively influences the attitude towards mobile voting.

In addition to the perceived usefulness and the perceived ease of use of mobile voting technology, we introduce a new component termed voting effort. This represents the perceived time and complexity entailed in the voting process. It is distinguished from perceived ease of use in that it explicitly assesses the respondents' opinion about the voting act itself (i.e. the evaluation of the film and the actors), whereas perceived ease of use captures merely the technical usability of the voting technology on the mobile device. We argue that integrating the effort associated with the effectuation of a mobile service constitutes a necessary extension of previous models as increased expended effort in terms of time, work or motivation counterbalances positive enhancements derived from other factors:

H6: Greater perceived voting effort has a negative impact on the attitude towards mobile voting.

\subsection{Beyond TAM and TPB}

TAM was originally developed to predict technology adoption in work or organizational contexts, and its parsimony was the big advantage of this model. In recent years however the two concepts of TAM and TPB have for the most part been applied in an integrated fashion, as it has reasonably been argued that the adoption of new technologies is also dependent upon the availability of resources and other factors which are not necessarily under volitional control. The models have also undergone several extensions. Addressing the criticisms that adoption processes in other contexts might differ substantially from those in work environments, traditional models have been amplified to include other determining components such as intrinsic motivations and enjoyment (Davis, Bagozzi, \& Warshaw, 1992), playfulness and anxiety (Venkatesh, 2000), and trust and risk in electronic commerce (Gefen, Karahanna, \& Straub, 2003; Pavlou, 2003). Integrated models have also been employed in studies of the adoption of electronic commerce (Pavlou \& Fygenson, 2006), in the adoption processes of mobile services in cross-service comparisons (Nysveen, et al., 2005), and in navigation prediction on the worldwide web (Agarwal \& Karahanna, 2000). With these models explaining around 70 per cent of the individual intention variance, Venkatesh et al. (2003) claim that research might have reached the limit of its 
predictive ability. There are, however, a number of issues that still remain unresolved. In particular, the adoption process in socially enriched environments has been neglected in previous research. We will therefore outline below the specific features of the adoption process in such settings.

\subsection{Adoption of Mobile Services in Socially Enriched Environments}

Baron, Patterson and Harris (2006) point to the fact that little is known about technology acceptance in social environments. Following the new services logic of marketing advanced by Vargo and Lusch (Stephen L. Vargo \& Lusch, 2008; 2004), they argue that technology use in social contexts is not merely a question of persuasion. Since consumers are co-creating the value of technology use, for example in short message writing (SMS), they actively embrace a new technology rather than simply accept it. In their qualitative study, Baron et al.(2006) were able to demonstrate that in marketplaces with strong community components social influence has an enhanced role in the adoption of technologies, and that technology adoption reflects individuals' need for relationships both with others and with social groups (Schau \& Gilly, 2003). Legris, Ingham and Collerrette (2003) claim that human and social change processes have to be taken into consideration when looking at technology acceptance. Previous research has mainly investigated technology acceptance of computer programs within organizations or professional environments (e.g. Park, Lee, \& Cheong, 2008). However, the adoption of mobile services might be strongly influenced by social components as their use is often embedded in socially enriched environments. To generate more insights into the adoption of mobile services, Wirth, von Pape and Karnowski (2008) have proposed an integrative model of mobile phone appropriation which accounts for the social side of mobile phone technologies, the interpersonally negotiated meanings of such technologies, and their relevance to users' social and self perceptions. With our research we take up the demand voiced by Baron et al. (2006) that social contexts should be researched in connection with technology acceptance, and we also tie up with the model of mobile phone appropriation put forward by Wirth, von Pape and Karnowski (2008). The technology itself under investigation, mobile voting, is characterized by an inherently highly social component: according to Festinger's (1954) social comparison theory, communicating one's own opinion and evaluating it in terms of opinions held by others represents a basic human need. The context of our research study is that of an online cinema community, thus the social influence can realistically be assumed to be present.

\subsection{Communities}

In marketing, the emerging phenomenon of consumption and brand communities has led to a dynamic body of research investigating these new forms of community. The idea of consumption communities centres on some special type of consumption (e.g. food, gifts) as part of a celebration, ritual or tradition (Muniz \& O'Guinn, 2001). Through technological advances in computer-mediated communication technologies, the Internet has served increasingly as a new platform for communication and exchange for such consumption communities. The emerging online communities are thus settings in which consumers participate in discussions whose goals include attempts to inform and influence fellow consumers regarding products and brands (Kozinets, 1999; Silva, Goel, \& Mousavidin, 2008). For consumption communities which centre on one particular brand, Muniz and O'Guinn (2001) developed the concept of brand communities which are "specialized, non-geographically bound communities, based on a structured set of social relationships among admirers of a brand" (p. 412). For marketers, increasing consumer activity on the Internet and in online communities is especially relevant as consumer advocacy seems to be the major factor influencing positive brand equity (Almquist \& Roberts, 2000; Berthon, Pitt, \& Campbell, 2008; Pitt, Watson, Berthon, Wynn, \& Zinkhan, 2006; Schouten, McAlexander, \& Koenig, 2007).

Porter (2004) went on to develop a typology of virtual communities and defines a virtual community as "an aggregation of individuals or business partners who interact around a shared interest, where the interaction is at least partially supported and/or mediated by technology and guided by some protocols or norms" (p.2). Thus, despite the members of virtual communities being geographically dispersed, they share their interests and exchange information in the Internet space and also share common socio-cultural properties, i.e. shared values, protocols and norms developed through the interaction among members. Evidently, a certain behavioral code developed within a community may exert normative pressure upon its members as to whether or not to perform certain behaviors. Thus the decision to use a new mobile service is no longer an exclusively individual one but instead reflects the values and positions of the social structure in which the individual is embedded. Applying this reasoning to the adoption of new mobile services, the social influence on behavior should in general be 
larger where individuals are interacting in communities. Although TAM and TPB models have sometimes been supplemented by situational factors, the main predicting path coefficients in most studies remain perceived usefulness and attitude towards behavior.

Table 1. Overview of studies modelling 'subjective norms' onto 'intention to try'

\begin{tabular}{|c|c|c|c|c|}
\hline Author/ Context & Context & $\begin{array}{l}\text { Mag. } \\
\text { Attitude }\end{array}$ & $\begin{array}{l}\text { Mag. } \\
\text { Perceived } \\
\text { behavioral } \\
\text { control }\end{array}$ & $\begin{array}{l}\text { Mag. } \\
\text { Subjective } \\
\text { Norms }\end{array}$ \\
\hline Davis et al. (1989) & $\begin{array}{l}\text { MBA-students, text editor } \\
\text { program }\end{array}$ & .55 & n.a. & .07 n.s. \\
\hline Mathieson (1991) & $\begin{array}{l}\text { Student } \\
\text { intro-management }\end{array}$ & $.49 * * *$ & $.41 * * *$ & n.s. \\
\hline Taylor and Todd (1995b & $\begin{array}{l}\text { Students, university computing } \\
\text { (non-stand. Values) }\end{array}$ & $1.15^{* * *}$ & $0.60 * * *$ & $0.20 * * *$ \\
\hline Taylor and Todd (1995a) & \multirow[t]{2}{*}{ Students, university computing } & $.02 /$ & $.16^{* * * /}$ & \multirow{2}{*}{$.09^{* * /} .16^{* *}$} \\
\hline $\begin{array}{ll}\text { Experienced } & \text { vs. } \\
\text { non-experienced users }\end{array}$ & & -.20 & $.50 * * *$ & \\
\hline \multirow[t]{3}{*}{ Karahanna et al. (1999) } & \multicolumn{4}{|l|}{ Windows in corporation } \\
\hline & Potential adopters & .28 & n.a. & $.46^{*}$ \\
\hline & Users & $.40 * * *$ & n.a. & $.01 \mathrm{n} . \mathrm{s}$. \\
\hline \multirow[t]{3}{*}{ Venkatesh and Morris (2000) } & Entire sample & & & .04 n.s. \\
\hline & Women (time 1 - time 3 ) & & & $\begin{array}{l}.33 * * *-.10 \\
\text { n.s. }\end{array}$ \\
\hline & Men (time 1 - time 3 ) & & & $\begin{array}{l}.08 \text { n.s. }-.09 \\
\text { n.s. }\end{array}$ \\
\hline Venkatesh et al. (2003) & Voluntary use in organizations & $.53 * * *$ & 0.07 n.s. & 0.02 n.s. \\
\hline Nysveen et al. (2005) & $\begin{array}{l}\text { Voluntary use of mobile } \\
\text { services }\end{array}$ & $.20 * *$ & $.09 * *$ & $.09 * *$ \\
\hline Pavlou and Fygenson (2006) & Online purchasing & $.61 * * *$ & $.23 * *$ & .04 n.s. \\
\hline$*<0.1, * *<0.5, * * *<0.01$ & & & & \\
\hline
\end{tabular}

Table 1 provides an overview of studies that have investigated the impact of subjective norms on the intention to perform certain behaviors. The findings are mixed, and Venkatesh et al. (2003) argue that the social norm component is important mainly in mandatory settings (Hartwick \& Barki, 1994). Furthermore the existing studies point towards the possibility that subjective norms impact only in the early stages of use when direct experience of a new technology is still small (Taylor \& Todd, 1995a), and this seems to be true only for women, whereas men do not seem to be affected at any time (Venkatesh \& Morris, 2000). In contrast, in communities where the use of technologies is voluntary and reflects social affiliation needs, we assume that the subjective norm component exercises a highly significant and - compared to previous studies - stronger impact on the intention to use a new technology, regardless of the individual's level of skill in using a mobile phone. With this argumentation in mind, we re-enforce $\mathrm{H} 2$, and propose:

$\mathrm{H} 2 / \mathrm{H} 7$ : The subjective norm has a strong impact on the intention to use the new technology.

\subsection{Rewards from Using Technologies in Social Environments}

An enhanced social influence on the intention to use a new mobile service is not the only particularity to be accounted for when investigating technology acceptance in community settings. In addition to the known antecedents from TAM and TPB, further determinants might also influence attitude and intention. From 
gratification research, Nysveen et al. (2005) have identified: a) enjoyment, fun seeking and entertainment and b) fashion, status and sociability as non-utilitarian gratifications that might impact on the use of mobile services.

Enjoyment represents the intrinsic motivation to use a technology (Igbaria, Parasuraman, \& Baroudi, 1996) and has been shown to have predictive power in various contexts. Initially the role of enjoyment was studied in the context of computer games (Holbrook, Chestnut, Oliva, \& Greenleaf, 1984). Davis, Bagozzi and Warshaw (1992) applied the concept to explain user acceptance of computers in the work place, and Dabholkar and Bagozzi (2002) discovered that enjoyment is a significant determinant in the attitude towards the use of technology-based self-services. As the use of mobile voting is based on voluntariness and lacks obvious extrinsic goal achievement factors, we assume that enjoyment is an important motivational driver for a positive attitude towards mobile voting. Thus we propose:

H8: Enjoyment positively influences the attitude towards mobile voting.

For many people the use of mobile phones constitutes a way of expressing their own personality. Leung and Wei (2000) found that fashion, status and sociability are important rewards which users can gain from the use of cellular phones. Nysveen et al. (2005) integrated this type of reward in their study and termed it expressiveness. They defined it as the degree to which users of mobile services perceived the service as suitable for expressing their emotions and their social or personal identity. We feel that among communities this dimension takes on even greater importance as the use of a mobile service is exercised within a socially enriched environment. Using a mobile service in this way is part of personal behavior which is overtly observable in public spaces to members of the community important to the individual. We term this dimension social value as the reward gained from the use of mobile services within a community is very much determined by the peer evaluation received from other community members. Wirth et al. (2008) in their appropriation model of mobile phone use, also suggest an amplification of the status dimension known from use-gratification research by stressing the symbolic function of mobile phone use with regard to oneself and with respect to one's social identity. Therefore, we propose:

H9: The expected social value derived from using mobile voting has a positive impact on the attitude towards mobile voting.

\subsection{Moderating Effects}

The theory of planned behavior suggests that people's intentions regarding behavior are influenced by three conceptually independent constructs: 1) attitude towards the behavior; 2) subjective norms; and 3) perceived behavioral control (Ajzen, 1985, 1991b, 1993, 2001). Although intention regarding behavior does not totally correspond with actual behavior, it serves as the most appropriate predictor of actual behavior (Ajzen, 1980; Armitage \& Christian, 2004; Fishbein \& Middlestadt, 1995). Whereas in Ajzen's early conceptualizations (cf. 1993), attitude was held to consist of cognition, affect, and conation, today the term attitude is most often used to refer to the affective component - the individual's overall good or bad feelings towards performing a behavior. In this study, it is this affective dimension to which we refer when using the term attitude. Although, salient cognitive beliefs may underlie one's attitude, the sufficiency assumption (cf. Ajzen, 2001; Loken, 1983) claims that the ability to predict accurately an individual's intention will not significantly increase as a result of adding additional variables. Therefore, we do not add additional variables to predict intention towards behavior, instead we test the impact on the relationships of our model of three moderating variables: involvement, skills, and consumers' innovation adoption.

\subsubsection{Involvement}

In marketing, product importance has been defined as a central component of enduring involvement (Beatty \& Talpade, 1994) and is an ongoing concern regarding an object or activity. In contrast to situational involvement, enduring involvement places emphasis on the product itself and the inherent satisfaction it provides (Bloch \& Richins, 1983). The characteristics of a high involvement are deep interest in the object or focal activity, greater enjoyment of the product or activity, and stronger identification with the product or activity (Kapferer \& Laurent, 1985). A high involvement leads to a more extensive information search and a greater knowledge base and has been used as a moderator both in models explaining consumers' attitudes and behavior in general (Homburg \& Giering, 2001) and in the theory of planned behavior in particular (Cooke \& Sheeran, 2004). It has been found that the attitudes of highly involved individuals are based on greater elaboration of relevant information, and that high involvement leads to more accessible attitudes and to a greater attitude-intention consistency (Cooke \& Sheeran, 2004). We assume that the degree of enduring involvement with - or the importance attached to cinema moderates paths in our model. We assume that enduring involvement pertains also towards cellular phones. As described by Leung and Wei (2000) people attach considerable importance to their mobile phones 
and consider them to be an important part of their daily lives. Therefore we expect that the importance attributed by individuals to mobile phones moderates relationships in our model.

Skills

From previous studies on technology acceptance we know that experience or usage time with a technology especially moderates social influences (Hartwick \& Barki, 1994; Taylor \& Todd, 1995a; Venkatesh, et al., 2003). Prior experience with the voting technology itself can be excluded in our study as this type of application is not yet a marketable product. However, we presume that the level of existing mobile phone skills might impact on the relationships in the main model. This view is supported by studies investigating flow, a construct which describes the optimal level of experience during network navigation (Czikszentmihalyi, 1977; Hoffman \& Novak, 1996). Existing skills are seen to be major determinants of whether flow experience can potentially occur (Novak, Hoffman, \& Yung, 2000). For example, it is likely that people with more highly developed mobile phone skills will evaluate the effort entailed in handling the mobile phone more critically and that perceived ease of use will not be as important for a positive attitude in this group of highly skilled users as for people with poor mobile phone skills. Hence, we expect skills to be a moderating variable in our model.

\subsubsection{Innovativeness}

Consumers differ in their reactions to new ideas, practices or objects due to their individual differences in innovativeness (Rogers, 1962), a trait describing the tendency toward adopting an innovation. Innovators and early adopters are more willing to take risks, try out new ideas ahead of others, and they find it easier to imagine, understand, and appreciate the benefits of innovations. According to innovation diffusion theory, it has been argued that early adopters can more easily envision the usefulness of a new technology than later adopters, and they can better recognize the compatibility of an innovation as they can better relate the innovation to their own needs, and given their knowledge, experience, technical competence and higher level of aspiration, they consider the same technology easier to use (Moore, 1999; Rogers, 2003; Yi, Fiedler, \& Park, 2006).

Previous research tested innovativeness in technology acceptance models both as a moderator as well as a mediator yielding somewhat inconsistent results. It has been found that innovativeness serves as a moderator and influences the impact of usefulness, ease of use, and compatibility on behavioral intention (R. Agarwal \& Prasad, 1998), but also that innovativeness has a direct and indirect effect (via usefulness, ease of use, and compatibility) on behavioral intention (Yi, et al., 2006). However, based on Ajzen's sufficiency assumption (cf. Ajzen, 2001; Loken, 1983), we do not add innovativeness as an additional independent variable in the model, but instead test its effect as a moderator, assuming that attitude formation processes and the impact of attitude on behavioral intention depend on the individual innovativeness of the consumer.

\section{The Study}

As mentioned in the introduction, the mobile voting technology featured in the study is not yet a marketable innovation but is still under development with various prototypes. Therefore, knowledge of the elements fostering technology adoption is crucial especially in the design phase of the application.

\subsection{Study Design}

To test a first version of the mobile voting application we have chosen a virtual cinema community, called moviemaze. It is an online platform specializing in movies in German-speaking countries. A large part is devoted to consumer interactivity, providing community members with forums to discuss movies, write reviews and recommendations, exchange opinions about actors, and also to discuss and share information about movie-related products, festivals, technological advances in film replay, etc. The web page attracts up to 300,000 visitors per month, and has around 2,000 registered community members. The invitation to participate in the study was announced in the community newsletter as well as through a banner on the front page of the web site and also via a link to the online survey next to information about the movie. Two movies had been selected for evaluation: a) $x X x 2$ - The Next Level, an action movie with Ice Cube, Samuel Jackson, and Willem Dafoe, and b) Star Wars: Episode III - The Revenge of the Sith, a science fiction movie with Ewan McGregor and Natalie Portman. Both movies had been launched in the US and Europe just at the time when the study was being carried out. As an incentive to participate in the study a prize draw with movie-related prizes was offered.

Since utilization of the mobile voting interface on cell phones has special technical requirements on the users' mobile devices, we have decided to test it via a virtual application on the Internet. Figure 1 shows the design of the empirical study. 


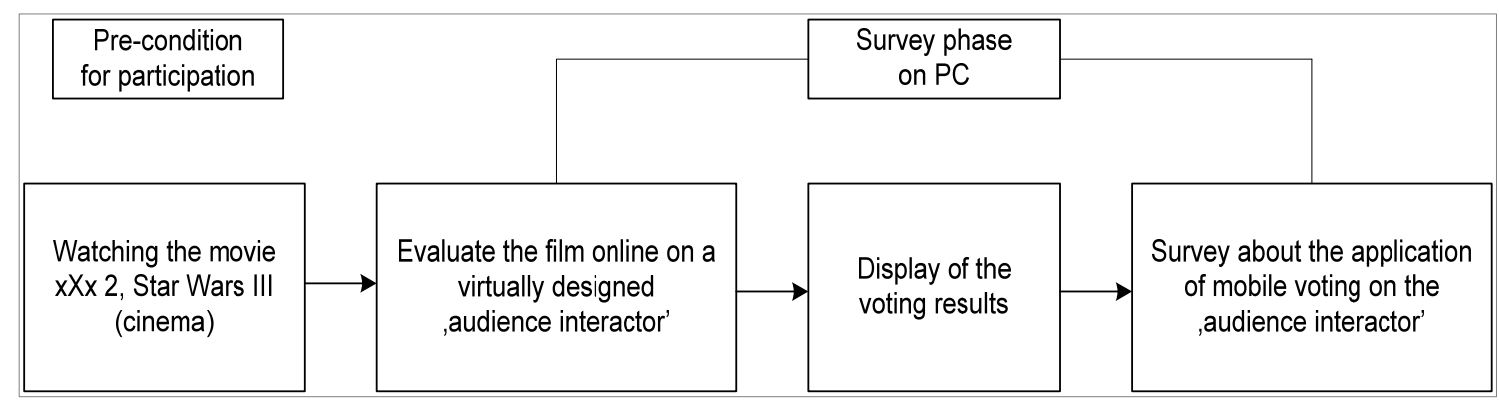

Figure 1. Conceptual design of the empirical online study

First, participants had to have watched one of the two movies in question in the cinema. After accepting the invitation to participate in the study, respondents accessed the questionnaire on the film via the link on the webpage of the cinema community moviemaze. The questions in this section were related to the film, and respondents answered questions exploring opinions concerning actors, the storyline and their like or dislike of the film. As regards question content, this part was of little interest for our study, but it was most important for the participants as at this point they were testing a virtual application of the mobile voting service. Respondents had to answer all the questions regarding the film as if they were operating a mobile phone held in their hands. To illustrate the possibilities of the mobile voting application, the questions were supported by images of movie scenes and actors. After finishing this first part of the study, the interim results of the voting were announced so that participants could immediately compare their own votes with the opinions of other community members. Finally, after subjects had looked at the voting results, the last section contained questions concerning the evaluation of the technology itself, the intention to use, the perceived ease of use and usefulness and all the other constructs of the research model described above. In total, 224 participants were recruited for the study. After excluding questionnaires that were not fully completed and cases with a completion time of less than four minutes, we arrived at 136 cases which were then used for further statistical analysis. The participants in the study were predominantly male ( $73 \%$ vs. $27 \%$ female), and on average 27 years old. We were not able to obtain detailed official viewer statistics as regards the age and gender of audiences for the two movies. However, we compared our sample to film evaluations posted by visitors on other web sites specializing in movies such as The Internet Movie Database (www.imdb.de). In these evaluations the participants had also been mainly male, and the predominating age groups were 18-29 and 30-44. Thus it is likely that our sample corresponds quiet well with other movie evaluation and audience statistics.

\subsection{Measures}

For all measurements, existing scales from the literature have been applied in a slightly modified version adapted to our context. Attitude towards behavior, subjective norm, perceived behavioral control, and intention to use have been assessed according to the scales proposed by Davis et al. (1989), Mathieson (1991), Taylor and Todd(1995a), and Venkatesh et al. (Venkatesh, et al., 2003). Perceived usefulness and perceived ease of use have also been measured using scales employed in the named studies. Enjoyment was measured on the scale developed by Nysveen et al. (2005). Social value was taken from Sweeney and Soutar (2001). For capturing the voting effort an appropriate scale has been developed. The moderating variables have been assessed on the basis of Beatty and Talpade (1994) for product involvement with cinemas and mobile phones. For measuring social value the scales of Sweeney and Soutar (2001) were adapted. Measures of mobile phone skills were taken from Novak et al. (2000). Consumers' innovativeness was measured with four items from the scale of global innovativeness from Goldsmith et al. (Goldsmith \& Freiden, 1995; Pallister \& Foxall, 1998), adapted to the context of the study and measured with 5-point Likert scales anchored with "strongly agree" and "strongly disagree", i.e.: "I am usually one of the first people in my group to download new mobile phone services", "When I hear about a new mobile phone service, I want to try it immediately", "Usually I am among the first of my group to know about newly introduced mobile phone services", "I must see other people using new product innovations before I will consider them." 


\section{Analysis and Results}

\subsection{Main Model}

To test our hypotheses we set up a structural equation model in AMOS 7.0. The parameter estimation was computed using Maximum-Likelihood estimation. Figure 2 displays the causal relationships of the main path model. The global fit measures indicate an adequate overall fit for the model. The local fit measures for the constructs (displayed in Table 2) meet all the required standards concerning average variance extracted (>.50), composite reliability $(>.60)$, and discriminant validity (Fornell-Larcker-Ratio $<1$ ). With our model we are able to explain $77 \%$ of the criterion variable intention to try. Attitude towards behavior is the most important predictor $(\beta=.72)$ for the intention to try mobile voting in future. Also subjective norms $(\beta=.27)$ significantly influence the intention to try, whereas perceived behavioral control has no significant impact on the intention to try mobile voting. As a favourable attitude seems to be the most important predictor for positive intentions, it is important to look at the determinants which foster a positive attitude. $83 \%$ of the attitude variance can be explained with the five integrated components of enjoyment, ease of use, effort, usefulness, and social value. Most importantly, the social factors enjoyment $(\beta=.50)$ and social value $(\beta=.22)$ are the main predictors for a positive attitude in the context of mobile service applications. The traditional components of the TAM, perceived ease of use $(\beta=.10)$ and usefulness $(\beta=.15)$ also contribute to a favourable attitude, but to a much lower degree than in traditional models. The voting effort itself has a negative impact on the attitude $(\beta=-.13)$.

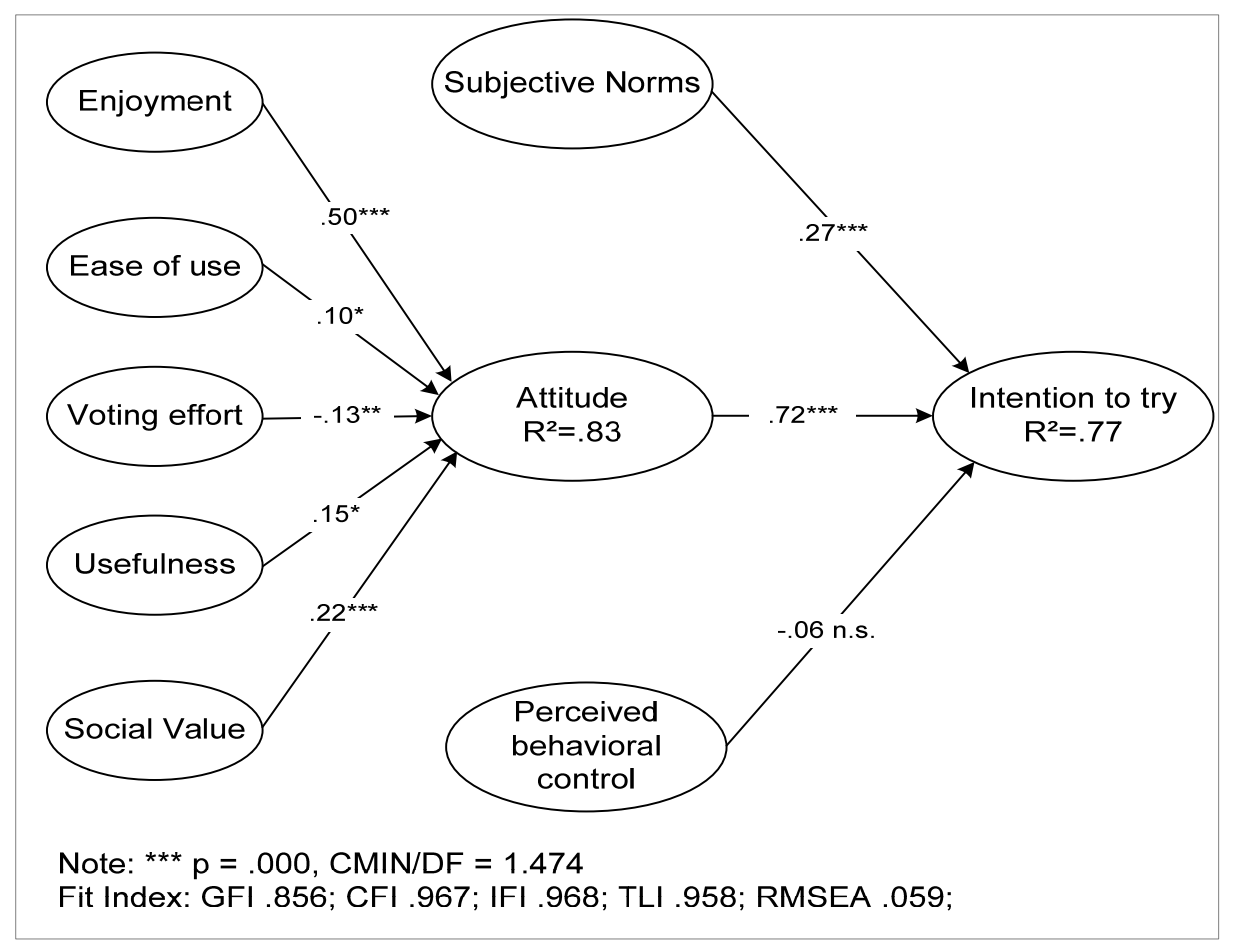

Figure 2. Results of the main model 
Table 2. Psychometric properties of constructs in the main model

\begin{tabular}{|c|c|c|c|c|c|}
\hline Construct & Item & $\begin{array}{l}\text { Factor } \\
\text { Loading }\end{array}$ & $\begin{array}{l}\text { Factor } \\
\text { Reliability }\end{array}$ & AVE & Fornell-Larcker-Ratio \\
\hline Enjoyment & $\begin{array}{l}\text { Participating in mobile } \\
\text { voting, was } \\
1 \text { Fun } \\
2 \text { Amusing } \\
3 \text { Enjoyable }\end{array}$ & $\begin{array}{l}.93 \\
.89 \\
.94\end{array}$ & .94 & .85 & .89 \\
\hline $\begin{array}{l}\text { Perceived ease of } \\
\text { use }\end{array}$ & $\begin{array}{l}\text { My interaction with the } \\
\text { system was } \\
1 \text { friendly } \\
2 \text { easy } \\
3 \text { clear and understandable }\end{array}$ & $\begin{array}{l}.85 \\
.90 \\
.86\end{array}$ & .90 & .76 & .76 \\
\hline Voting effort & $\begin{array}{l}1 \text { Mobile Voting is } \\
\text { time-consuming. } \\
2 \text { The participation was } \\
\text { complex }\end{array}$ & $\begin{array}{l}.91 \\
.84\end{array}$ & .87 & .77 & .28 \\
\hline Usefulness & $\begin{array}{l}1 \text { Using the system would } \\
\text { enable me to } \\
\text { evaluate films more } \\
\text { quickly } \\
2 \text { Using the system would } \\
\text { make it easier to } \\
\text { retain information } \\
3 \text { Using the system makes it } \\
\text { easier to get in } \\
\text { contact with others }\end{array}$ & $\begin{array}{l}.77 \\
.67 \\
.84\end{array}$ & .81 & .59 & .90 \\
\hline Social Value & $\begin{array}{l}\text { Mobile Voting within the } \\
\text { community helps me } \\
1 \text { to improve the way I am } \\
\text { perceived } \\
2 \text { to make a good impression } \\
\text { on other people } \\
3 \text { to be associated to the } \\
\text { community }\end{array}$ & $\begin{array}{l}.93 \\
.89 \\
.85\end{array}$ & .92 & .79 & .71 \\
\hline Attitude & $\begin{array}{l}\text { Mobile Voting is } \\
1 \text { good .... bad } \\
2 \text { helpful .... not helpful } \\
3 \text { cool .... stupid }\end{array}$ & $\begin{array}{l}.84 \\
.89 \\
.94\end{array}$ & .92 & .80 & .95 \\
\hline Subjective norms & $\begin{array}{l}1 \text { People who influence my } \\
\text { behavior think that } \\
\text { I should use Mobile } \\
\text { Voting } \\
2 \text { My friends would } \\
\text { appreciate it if I used the } \\
\text { Mobile Voting system }\end{array}$ & .92 & .94 & .89 & .60 \\
\hline $\begin{array}{l}\text { Perceived } \\
\text { behavioral } \\
\text { control }\end{array}$ & $\begin{array}{l}1 \mathrm{I} \text { had full control over the } \\
\text { Mobile Voting } \\
\text { system } \\
1 \mathrm{I} \text { intend to use the Mobile }\end{array}$ & .52 & 1.00 & 1.00 & .28 \\
\hline Intention to try & $\begin{array}{l}\text { Voting system } \\
2 \text { Probably I will use the } \\
\text { Mobile Voting system }\end{array}$ & $\begin{array}{l}.98 \\
.88\end{array}$ & .93 & .86 & .86 \\
\hline
\end{tabular}




\subsection{Moderating Effects}

For the purpose of testing the hypothesized moderating effects we first analyzed the scale reliabilities of the measures used and received satisfactory values for all scales: involvement with cinema $(\beta=.945)$, involvement with cell phones $(\beta=.895)$, cell phone skills $(\beta=.793)$, and consumers' innovativeness $(\beta=.915)$. We created two subgroups for each scale, one group with high-scorers and one group representing low-scorers on each scale. The group division was effected by median split. Then we conducted a multi-group analysis with Amos 7.0. Testing the model comparison used two models, a restricted model, which forces the parameters in the model to be equal across groups and a more general model, which allows these parameters to vary across groups. If $\chi^{2}$ improves significantly when moving from the restricted to the more general model, the exogenous latent variables have a differential effect on the dependent variable, and the respective variable can be seen as a moderator. Significance is assessed on the basis of the $\chi^{2}$-difference between the models with the use of a $\chi^{2}$-distribution with one degree of freedom. In the first step of the moderator analysis, an overall $\chi^{2}$-difference test for the moderator variable was conducted. Two models - one that imposes equality constraints on the parameters across subgroups, and a general model that allows these parameters to vary freely across subgroups were compared. The null hypothesis assumes that the proposed variables do not have any effect on the relationships of latent constructs in the model. This null hypothesis must be rejected, as the $\Delta \chi^{2}$ with all parameters set equal across subgroups is significant for all three moderating variables: thus involvement with cinema and cell phones, skills, and consumers' innovativeness all significantly moderate the relationships in the main model. Table 3 displays the results of the moderating analysis in detail.

Involvement with cinema moderates two functional paths in the model: ease of use of the technical device is less important for those with high cinema involvement than for those with low involvement. The same moderating effect appears to be true also for people with high involvement with cell phones and people with high cell phone skills. These findings are plausible as the heightened interest in cinema and/or cell phones might compensate for deficits in the ease of use. This logic however is not true for perceived usefulness, as this component is equally important for all groups. This supports the widely-accepted notion outlined in the theoretical section of our paper that usefulness is a necessary requirement for technology adoption (Davis, et al., 1989). The voting effort component is a further moderated path, with similar patterns under all moderating conditions: the voting effort is a more important determinant for a positive attitude in people with high cinema and/or cell phones involvement, or with high cell phone skills, than in those with low scores on these dimensions. This might be attributed to the fact that, due to the heightened interest and knowledge of highly involved individuals in the respective field, they evaluate new applications and innovations in the field more critically. Finally the two social components in the model are moderated. Social value seems to be a stronger determinant for a positive attitude for people with low cell phone involvement, whereas for those with high cell phone skills the enjoyment of the mobile service application is more important for a positive attitude. This means that for people with high technical know-how on the cell phone enjoyment is a prevailing determinant for a positive attitude, whereas for those with little cell phone involvement the possible social value derived from the social interaction of the mobile voting process is more important. Confirming our assumptions, the level of cell phone skills does not moderate the relationship between subjective norms and the intention to try mobile voting. This finding corroborates our assumption in hypotheses $\mathrm{H} 2 / \mathrm{H} 7$ in which we predicted that the impact of the subjective norms arising from the social structure of communities on the intention to use mobile voting would not be moderated by skills, as has been found in previous studies (Taylor \& Todd, 1995a). 
Table 3. Results of the moderator analysis

\begin{tabular}{|c|c|c|c|}
\hline \multirow[t]{2}{*}{ Path } & \multicolumn{2}{|c|}{ Involvement Cinema (Beatty/Talpade 1994) } & \multirow[t]{2}{*}{$\begin{array}{l}\text { Chi-Square difference } \\
(\Delta \mathrm{DF}=1)\end{array}$} \\
\hline & High & Low & \\
\hline Eouse - attitude & $=.028(\mathrm{t}=.384 \mathrm{~ns})$ & $=.235(\mathrm{t}=2.4144 * * *)$ & $\Delta \chi^{2}=2.816 *$ \\
\hline Effort - attitude & $=-.202(\mathrm{t}=-3.333 * * *)$ & $=-.039(\mathrm{t}=-.493 \mathrm{~ns})$ & $\Delta \chi^{2}=5.458 * * *$ \\
\hline \multicolumn{4}{|c|}{$\Delta \chi^{2}$ for all gammas set equal across subgroups $(\Delta \mathrm{DF}=8): 17.399 * *$} \\
\hline \multicolumn{4}{|c|}{$\Delta \chi^{2}$ for measurement weights set equal across subgroups $(\Delta \mathrm{DF}=13): 21.097 *$} \\
\hline \multirow[t]{2}{*}{ Path } & \multicolumn{2}{|c|}{ Involvement Cell phone (Moorthy et al. 1997) } & $\begin{array}{l}\text { Chi-Square difference } \\
(\triangle \mathrm{DF}=1)\end{array}$ \\
\hline & High & Low & \\
\hline Eouse - attitude & $=-.005(\mathrm{t}=-.63 \mathrm{~ns})$ & $=.329(\mathrm{t}=3.085 * * *)$ & $\Delta \chi^{2}=6.635 * * *$ \\
\hline Effort - attitude & $=-.166(\mathrm{t}=-2.310 * *)$ & $=-.045(\mathrm{t}=-.455 \mathrm{~ns})$ & $\Delta \chi^{2}=2.797 *$ \\
\hline Social value - attitude & $=.141(\mathrm{t}=1.615 *)$ & $=.469(\mathrm{t}=2.771 * * *)$ & $\Delta \chi^{2}=2.831 *$ \\
\hline \multicolumn{4}{|c|}{$\Delta \chi^{2}$ for all gammas set equal across subgroups $(\Delta \mathrm{DF}=8): 17.399 * *$} \\
\hline \multicolumn{4}{|c|}{$\Delta \chi^{2}$ for measurement weights set equal across subgroups $(\Delta \mathrm{DF}=13): 21.097 *$} \\
\hline \multirow[t]{2}{*}{ Path } & \multicolumn{2}{|c|}{ Skills (Hippel 1996, Novak et al. 2000) } & $\begin{array}{l}\text { Chi-Square difference } \\
(\Delta \mathrm{DF}=1)\end{array}$ \\
\hline & High & Low & \\
\hline Enjoyment - attitude & $=.488\left(\mathrm{t}=4.836^{* * *}\right)$ & $=.241(\mathrm{t}=2.492 * * *)$ & $\Delta \chi^{2}=3.072 *$ \\
\hline Eouse - attitude & $=-.095(\mathrm{t}=-1.187 \mathrm{~ns})$ & $=.237(\mathrm{t}=2.879 * * *)$ & $\Delta \chi^{2}=8.164 * * *$ \\
\hline Effort - attitude & $=-.261(\mathrm{t}=-2.866 * * *)$ & $=.030(\mathrm{t}=.429 \mathrm{~ns})$ & $\Delta \chi^{2}=4.098 * *$ \\
\hline \multicolumn{4}{|c|}{$\Delta \chi^{2}$ for all gammas set equal across subgroups $(\Delta \mathrm{DF}=8): 15,872 * *$} \\
\hline \multicolumn{4}{|c|}{$\Delta \chi^{2}$ for measurement weights set equal across subgroups $(\Delta \mathrm{DF}=13): 11,411 \mathrm{~ns}$} \\
\hline \multirow[t]{2}{*}{ Path } & \multicolumn{2}{|c|}{ Consumer's innovativeness } & $\begin{array}{l}\text { Chi-Square difference } \\
(\Delta \mathrm{DF}=1)\end{array}$ \\
\hline & High & Low & \\
\hline $\begin{array}{l}\text { Subjective norms - } \\
\text { intention to try }\end{array}$ & $=.172(\mathrm{t}=1.290 \mathrm{~ns})$ & $=.456(\mathrm{t}=3.959 * * *)$ & $\Delta \chi^{2}=2.192+$ \\
\hline Attitude - intention to try & $=.484(\mathrm{t}=5.771 * * *)$ & $=.692(\mathrm{t}=4.670 * * *)$ & $\Delta \chi^{2}=6.018 * * *$ \\
\hline Social value - attitude & $=.152(\mathrm{t}=1.786 *)$ & $=.394(\mathrm{t}=2.805 * * *)$ & $\Delta \chi^{2}=1.98+$ \\
\hline \multicolumn{4}{|c|}{$\Delta \chi^{2}$ for all gammas set equal across subgroups $(\Delta \mathrm{DF}=8): 14.144 *$} \\
\hline$\Delta \chi^{2}$ for measurement weig & s set equal across subgr & $(\Delta \mathrm{DF}=13): 7.204 \mathrm{~ns}$ & \\
\hline
\end{tabular}

\section{Conclusions and Implications}

In this study we have developed a model to explain the adoption of new mobile service applications by integrating the technology acceptance model and the theory of planned behavior. In previous research it has been argued that by integrating control, intrinsic motivation, and emotion into the technology acceptance model, the limits of predictive ability have been reached (Venkatesh, 2000). However, research in customer perceived value has shown that social value is an important value dimension (Sweeney \& Soutar, 2001). We developed the hypothesis that in a socially enriched environment the adoption and use of a mobile service is not a mere question of persuasion, but that the individual's decision to adopt the new service is also affected by the need for 
relationships with others in social groups. The model shows that the social value of the new technology - i.e. the reward gained from the use of the new mobile service through enhancing the consumer's self image - does indeed influence the attitude towards the new service. Given the increasing importance of online communities (Füller, Jawecki, \& Mühlbacher, 2007) and brand communities (Muniz and O'Guinn 2001), this is an important extension of technology acceptance models as it has been shown that in a highly interactive and socially enriched environment, social value may well increase predictive ability.

Another extension of TAM is the construct voting effort, which in the context of our study seemed to be a relevant determinant of attitude, being another facet of the customer's perception of the technology. Whereas perceived usefulness and perceived ease of use capture the usability of the technology and the integration of the voting technology on the mobile device, our construct voting effort (time and complexity) represents the perceived effort needed to use the technology. This is conceptually and empirically different from perceived usefulness and perceived ease of use and thus is a necessary extension of previous models.

As has already been shown in previous studies (Igbaria, et al., 1996), enjoyment also positively influences the attitude towards mobile voting.

With regard to the TPB components integrated in our model, a major finding of our study is that the subjective norm has a strong impact on the intention to use the new technology. This finding differs from previous studies, which found little or no influence of social norms, leading to the conclusion that the subjective norm is mainly important in mandatory settings (Venkatesh, et al., 2003), or in early stages of use when there is little experience with the new technology (Taylor \& Todd, 1995a). In the context of our study, where the use of the technology is voluntary and where there is social affiliation with online community members, the subjective norms component has a highly significant impact - regardless of individual's cell phone skill level.

Finally, as we expected, involvement with the cinema, involvement with cell phones, skills, and a consumer's innovativeness all moderate several relationships within our model. This constitutes an important contribution to theory as these findings help to predict those situations in which the individual components of TAM and TPB have a strong or weak influence on attitudes and intentions.

Overall, the theoretical contribution of our paper lies in the extension of existing models that try to explain the acceptance of new mobile services by integrating TAM and TPB and including appropriate variables that account for the particularities of the adoption behavior in the context of socially enriched environments. From a managerial point of view, this finding is relevant as the predictive ability of the model is increased. Perhaps surprisingly to some managers, our results suggest that the traditional "hard" factors of usefulness and ease of use are of only secondary importance for potential customers of mobile voting services. These factors may be regarded as basic requirements (though differing depending upon involvement and skills), but the most important drivers to use such services are enjoyment and the social value associated with their use. Therefore, managers should emphasize and support these values throughout product development and in external communication during the market introduction. Taking into account potential customers' needs for fun and social recognition might prevent otherwise promising technology from suffering the fate of low diffusion suffered by some other mobile services. Our results further suggest that mobile voting services may well diffuse only if communities rather than individuals decide to use such a service. Therefore, in addition to the mobile voting application, managers may offer community platforms and interfaces to existing social networks such as Facebook in order to increase the value of such a service as perceived by consumers.

\section{Limitations}

As the technology featured in the study was actually not yet on the market a virtual application was tested. Although a lot of effort was put into the creation of an extremely realistic virtual environment for the application of the mobile voting service, the use of a virtual application inevitably constitutes a limitation of our study. A second limitation pertains to the use of intention as a substitute for actual behavior. Again, as the technology was not yet on the market, actual adoption behavior could not be measured. Moviemaze is a major and a highly interactive online community in Germany, with members who discuss movies, write film reviews and recommendations, and exchange opinions, etc. Hence, it represents a suitable population for testing technology acceptance in a socially enriched environment. Nevertheless, generalizability issues still remain, e.g. do online communities differ from off-line communities? 


\section{References}

Agarwal, R., \& Prasad, J. (1998). A conceptual and operational definition of personal innovativeness in the domain of information technology. Information Systems Research, 9(2), 204-215. http://dx.doi.org/10.1287/ isre.9.2.204

Agarwal, R., \& Karahanna, E. (2000). Time flies when you're having fun: cognitive absorption and beliefs about information technology usage. MIS Quaterly, 24(4), 665-694. http://dx.doi.org/10.2307/3250951

Ajzen, I. (1980). Understanding Attitudes and Predicting Social Behavior. Englewood-Cliffs, NJ: Prentice-Hall.

Ajzen, I. (1985). From intentions to action: a theory of planned behavior. In J. Kuhl \& J. Beckman (Eds.), Action-Control: From Cognition to Behavior (pp. 11-38). Heidelberg: Springer.

Ajzen, I. (1988). Attitudes, personality, and behavior. Milton Keynes: Open University Press.

Ajzen, I. (1991a). The theory of planned behavior. Organizational Behavior and Human Processes, 50, 179-211. http://dx.doi.org/10.1016/0749-5978(91)90020-T

Ajzen, I. (1991b). The Theory of Planned Behavior. Organizational Behavior \& Human Decision Processes, 50(2), 179-211. http://dx.doi.org/10.1016/0749-5978(91)90020-T

Ajzen, I. (1993). Attitude Theory and the Attitude-Behavior Relation. In Dagmar Krebs \& Peter Schmidt (Eds.), New Directions in Attitude Measurement (pp. 41-58). Berlin: Walter de Gruyter.

Ajzen, I. (2001). Nature and Operation of Attitudes. Annual Review of Psychology, 52, 27-58. http://dx.doi.org/ 10.1146/annurev.psych.52.1.27 PMid:11148298

Ajzen, I. (2002). Perceived behavioral control, self-efficacy, locus of control, and the theory of planned behavior. Journal of Applied Social Psychology, 32(4), 665-683. http://dx.doi.org/10.1111/j.1559-1816.2002.tb0023 6.x

Ajzen, I., \& Fishbein, M. (1980). Understanding attitudes and predicting social behavior. Englewood Cliffs, NJ: Prentice-Hall.

Almquist, E., \& Roberts, K. J. (2000). A 'mindshare manifesto'. Mercer Management Journal, 12, 9-20.

Armitage, C. J., \& Christian, J. (2004). Planned behavior: The relationship between human thought and action. New Brunswick, NJ: Transaction Publishers.

Baron, S., Patterson, A., \& Harris, K. (2006). Beyond technology acceptance: understanding consumer practice. International Journal of Service Industry Management, 17(2), 111-135. http://dx.doi.org/10.1108/095642 30610656962

Beatty, S. E., \& Talpade, S. (1994). Adolescent influence in family decision making: a replication with extension. Journal of Consumer Research, 21, 332-341. http://dx.doi.org/10.1086/209401

Berthon, P., Pitt, L. F., \& Campbell, C. (2008). Ad Lib: When Customers Create the Ad. California Management Review, 50(4), 6-30.

Bloch, P. H., \& Richins, M. L. (1983). A theoretical model for the study of product importance perceptions. Journal of Marketing, 47, 69-81. http://dx.doi.org/10.2307/1251198

Bucy, E. P. (2004). Interactivity in society: locating an elusive concept. The Information Society, 20, 373-383. http://dx.doi.org/10.1080/01972240490508063

Cooke, R., \& Sheeran, P. (2004). Moderation of cognition-intetnion and cognition-bheavior relations: A meta-analysis of properties of variables from the theory of planned behavior. Bristish Journal of Social Psychology, 43, 159-186. http://dx.doi.org/10.1348/0144666041501688 PMid:15285829

Czikszentmihalyi, M. (1977). Beyond boredom and anxiety. San Francisco: Jossey -Bass.

Dabholkar, P., \& Bagozzi, R. P. (2002). An attitudinal model of technology-based self-service: moderating effects of consumer traits and situational factors. Journal of the Academy of Marketing Science, 30(3), 184-202.

Davis, F. D. (1989). Perceived usefulness, perceived ease of use, and user acceptance of information technology. MIS Quaterly, 319-340.

Davis, F. D., Bagozzi, R. P., \& Warshaw, P. R. (1989). User acceptance of computer technology: a comparison of two theoretical models. Management Science, 35(8), 982-1003. http://dx.doi.org/10.1287/mnsc.35.8.982 
Davis, F. D., Bagozzi, R. P., \& Warshaw, P. R. (1992). Extrinsic and intrinsic motivation to use computers in the workplace. Journal of Applied Social Psychology, 22(14), 1111-1132. http://dx.doi.org/10.1111/j.1559-18 16.1992.tb00945.x

Festinger, L. (1954). A theory of social comparison processes. Human Relations, 7, 117-140. http://dx.doi.org/ $10.1177 / 001872675400700202$

Fishbein, M., \& Middlestadt, S. (1995). Noncognitive Effects on Attitude Formation and Change: Fact of Artifact? Journal of Consumer Psychology, 4(2), 181-202. http://dx.doi.org/10.1207/s15327663jcp0402_05

Füller, J., Jawecki, G., \& Mühlbacher, H. (2007). Innovation creation by online basketball communities. Journal of Business Research, 60(1), 60-71. http://dx.doi.org/10.1016/j.jbusres.2006.09.019

Gefen, D., Karahanna, E., \& Straub, D. W. (2003). Trust and TAM in online shopping: an integrated model. MIS Quaterly, 27(1), 51-90.

Goldsmith, R., \& Freiden, J. (1995). The generality/specifity issue in consumer innovativeness research. Technovation, 15(10), 601-612. http://dx.doi.org/10.1016/0166-4972(95)99328-D

Hartwick, K., \& Barki, H. (1994). Explaining the role of user participation in information system use. Management Science, 40(4), 440-465.

Hoffman, D. L., \& Novak, T. P. (1996). Marketing in hypermedia computer-mediated environments: conceptual foundations. Journal of Marketing, 60, 50-68. http://dx.doi.org/10.2307/1251841

Holbrook, M. B., Chestnut, R. W., Oliva, T. A., \& Greenleaf, E. A. (1984). Play as consumption experience: The roles of emotions, performance, and personality in the enjoyment of games. Journal of Consumer Behavior, $11,728-739$.

Homburg, C., \& Giering, A. (2001). Personal characteristics as moderators of the relationship between customer satisfaction and loyalty - An empirical analysis. Psychology \& Marketing, 18(1), 43-66. http://dx.doi.org/10. 1002/1520-6793(200101)18:1<43::AID-MAR3>3.0.CO;2-I

Igbaria, M., Parasuraman, S., \& Baroudi, J. J. (1996). A motivational model of microcomputer usage. Journal of Management Information Systems, 13(1), 127-143.

Kapferer, J. N., \& Laurent, G. (1985). Consumers' Involvement Profile: New Empirical Results. Advances in Consumer Research, 12, 290-295.

Karahanna, E., Straub, D. W., \& Chervany, N. (1999). Information technology adoption across time: a cross-sectional comparison of pre-adoption and post-adoption beliefs. MIS Quaterly, 23(2), 183-213.

Kim, H., Kim, G. J., Park, H. W., \& Rice, R. E. (2007). Configurations of relationships in different media: FtF, email, instant messenger, mobile phone, and SMS. Journal of Computer-Mediated Communication, 12, 1183-1207. http://dx.doi.org/10.1111/j.1083-6101.2007.00369.x

Kozinets, R. V. (1999). E-tribalized marketing? The strategic implications of virtual communities of consumption. European Managment Journal, 17(3), 252-264. http://dx.doi.org/10.1016/S0263-2373(99)00 004-3

Legris, P., Ingham, J., \& Collerette, P. (2003). Why do people use information technology? A critical review of the technology acceptance model. Information \& Managment, 40, 191-204. http://dx.doi.org/10.1016/S0378 $-7206(01) 00143-4$

Leung, L., \& Wei, R. (2000). More than just talk on the move: uses and gratifications of the cellular phone. Journalism and Mass Communication Quarterly, 77, 308-320. http://dx.doi.org/10.1177/107769900007700 206

Loken, B. (1983). The Theory of Reasoned Action: Examination of the Sufficiency Assumption for a Television Viewing Behavior. Advances in Consumer Research, 10(1), 100-105.

Lu, Y., Deng, Z., \& Wang, B. (2010). Exploring factors affect in Chinese consumrs' usage of short message service for personal communication. Information Systems Journal, 20, 183-208.

Mahatanankoon, P., \& O'Sullivan, P. (2008). Attitude towards mobile text messaging: an expectancy-based perspective. Journal of Computer-Mediated Communication, 13, 973-992. http://dx.doi.org/10.1111/j.1083 $-6101.2008 .00427 . \mathrm{x}$

Mathieson, K. (1991). Predicting user intentions: comparing the technology acceptance model with the theory of planned behavior. Information Systems Research, 2(3), 173-191. http://dx.doi.org/10.1287/isre.2.3.173 
Meso, P., Musa, P., \& Mbarika, V. (2005). Towards a model of consumer use of mobile information and communication technology in LDCs: the case of sub-Saharan Africa. Information Systems Journal, 15, 119-146. http://dx.doi.org/10.1111/j.1365-2575.2005.00190.x

Moore, G. A. (1999). Crossing the chasm (2nd ed.). New York: Harper Collins.

Muniz, A. M., \& O'Guinn, T. C. (2001). Brand community. Journal of Consumer Research, 27, 412-432. http://dx.doi.org/10.1086/319618

Novak, T. P., Hoffman, D. L., \& Yung, Y. F. (2000). Measuring the customer experience in online environments: a structural modeling approach. Marketing Science, 19(1), 22-42. http://dx.doi.org/10.1287/ mksc.19.1.22.15184

Nysveen, H., Pedersen, P. E., \& Thorbjornsen, H. (2005). Intentions to use mobile services: antecedents and cross-service comparisons. Journal of the Academy of Marketing Science, 33(3), 330-346. http://dx.doi.org/10.1177/0092070305276149

Pallister, J., \& Foxall, G. (1998). Psychometric properties of the Hurt-Joseph-Cook scales for themeasurement of innovativeness. Technovation, 18(11), 663-675. http://dx.doi.org/10.1016/S0166-4972(98)00070-4

Park, N., Lee, K. M., \& Cheong, P. H. (2008). University instructors' acceptance of electronic courseware: an application of the technology accpetance model. Journal of Computer-Mediated Communication, 13, 163-186. http://dx.doi.org/10.1111/j.1083-6101.2007.00391.x

Pavlou, P. A. (2003). Consumer acceptance of electronic commerce: integrating trust and risk with the technology acceptance model. International Journal of Electronic Commerce, 7(3), 69-103.

Pavlou, P. A., \& Fygenson, M. (2006). Understanding and predicting electronic commerce adoption: an extension of the theory of planned behavior. MIS Quaterly, 30(1), 115-143.

Pitt, L.F., Watson, R. T., Berthon, P., Wynn, D., \& Zinkhan, G. M. (2006). The Penguin's Window: Corporate Brand From an Open-Source Perspective. Journal of the Academy of Marketing Science, 34(2), 115-127. http://dx.doi.org/10.1177/0092070305284972

Porter, C. E. (2004). A typology of virtual communities: a multi-disciplinary foundation for future research. Journal of Computer-Mediated Communication, 10(1).

Rafaeli, S. (1988). Interactivity: from new media to communication. In R. Hawkins, J. Wiemann \& Pingree. S. (Eds.), Advancing communication science: merging mass and interpersonal processes (pp. 110-134). Newbury Park: Sage.

Rogers, E. M. (1962). Diffusion of Innovations. New York: Free Press.

Rogers, E. M. (2003). Diffusion of innovations (5th ed. ed.). New York: The Free Press.

Schau, H. J., \& Gilly, M. C. (2003). We are what we post? Self-presentation in personal web space. Journal of Consumer Research, 30, 385-404. http://dx.doi.org/10.1086/378616

Schouten, J. W., McAlexander, J. H., \& Koenig, H. F. (2007). Transcendent Customer Experience and Brand Community. Journal of the Academy of Marketing Science, 35(3), 357-368. http://dx.doi.org/10.1007/s11747-007-0034-4

Silva, L., Goel, L., \& Mousavidin, E. (2008). Exploring the dynamics of blog communiteis: the case of MetaFilter. Information Systems Journal, 19, 55-81. http://dx.doi.org/10.1111/j.1365-2575.2008.00304.x

Steuer, J. (1992). Defining virtual reality: dimensions determining telepresence. Journal of Communication, 42(4), 73-93. http://dx.doi.org/10.1111/j.1460-2466.1992.tb00812.x

Subramanian, G. H. (1994). A replication of perceived usefulness and perceived ease of use measurement. Decision Science, 25(5/6), 863-874. http://dx.doi.org/10.1111/j.1540-5915.1994.tb01873.x

Sultan, F., \& Rohm, A. (2005). The coming era of 'brand in the hand' marketing. MIT Sloan Management Review, 47(1), 83-89.

Sweeney, J. C., \& Soutar, G. N. (2001). Consumer perceived value: the development of a multiple item scale. Journal of Retailing, 77, 203-220. http://dx.doi.org/10.1016/S0022-4359(01)00041-0

Taylor, S., \& Todd, P. A. (1995a). Assessing IT usage: the role of prior experience. MIS Quaterly, 19(4), 561-570. http://dx.doi.org/10.2307/249633 
Taylor, S., \& Todd, P. A. (1995b). Understanding information technology usage: a test of competing models. Information Systems Research, 6(2), 144-176. http://dx.doi.org/10.1287/isre.6.2.144

Vargo, S. L., \& Lusch, R. F. (2008). Service-dominant logic: continuing the evolution. Journal of the Academy of Marketing Science, 36(1), 1-10. http://dx.doi.org/10.1007/s11747-007-0069-6

Vargo, S. L., \& Lush, R. F. (2004). Evolving to a new dominant logic of marketing. Journal of Marketing, 68, 1-17. http://dx.doi.org/10.1509/jmkg.68.1.1.24036

Venkatesh, V. (2000). Determinants of perceived ease of use: integrating control, intrinsic motivation, and emotion into the Technology Acceptance Model. Information Systems Research, 11(4), 342-365. http://dx.doi.org/10.1287/isre.11.4.342.11872

Venkatesh, V., \& Morris, M. G. (2000). Why do men ever stop to ask for directions? Gender, social influence, and their role in technology acceptance and usage behavior. MIS Quaterly, 24(1), 115-139. http://dx.doi.org/10.2307/3250981

Venkatesh, V., Morris, M. G., Davis, G. B., \& Davis, F. D. (2003). User acceptance of information technology: toward a unified view. MIS Quaterly, 27(3), 425-478.

Wang, Y. S., Lin, H. H., \& Luarn, P. (2006). Predicting consumer intention to use mobile service. Information Systems Journal, 16,(157-179). http://dx.doi.org/10.1111/j.1365-2575.2006.00213.x

Watson, R. T., Pitt, L. F., Berthon, P., \& Zinkhan, G. (2002). U-Commerce: expanding the universe of marketing. Journal of the Academy of Marketing Science, 30(4), 333-347. http://dx.doi.org/10.1177/009207002236909

Wirth, W., von Pape, T., \& Karnowski, V. (2008). An integrative model of mobile phone appropriation. Journal of Computer-Mediated Communication, 13, 593-617. http://dx.doi.org/10.1111/j.1083-6101.2008.00412.x

Yi, M. Y., Fiedler, K. D., \& Park, J. S. (2006). Understanding the role of individual ainnovativeness in the acceptance of IT-based innovations: comparative analyses of models and measures. Decision Science, 37(3), 393-426. http://dx.doi.org/10.1111/j.1540-5414.2006.00132.x 